\title{
EFEKTIVITAS PELATIHAN PEMBUATAN PMT MODISCO TERHADAP PENGETAHUAN IBU DI KELURAHAN TANJUNGREJO KECAMATAN SUKUN KOTA MALANG
}

\author{
Yeni Susanti \\ Mazarina Devi \\ Septa Katmawanti \\ Fakultas Ilmu Keolahragaan Universitas Negeri Malang \\ email: yenisusanti595@gmail.com
}

\begin{abstract}
Modisco (Modified Dietetic Skim and Cotton Sheet Oil) is an additional food that contains high calories to increase the children's weights. The procedure to make PMT modisco is very easy because it consists of three basic ingredients which are skim milk, sugar and margarine. This study aims to know the effect of the training to the mother knowledge in making PMT modisco, the training was done by using lecture and demonstration method. The research design used is preexperimental by using one group pretest and posttes method. The data for knowledge used questionnaire while the data. The samples in this study were all of the mothers who have Bawah Garis Merah (BGM) children in the village of Tanjungrejo Sub-district of Sukun District of Malang that were 11 people. The result is knowledge data using paired samplet t-test that obtained the score of Sig. (2tailed) was $0.000<0.05$ which means there is the effectiveness of training to the mothers' knowledge related to PMT modisco. The procedure of making module PMT is not too difficult, there are three basic ingredients modisco in training abbreviated with milk, sugar, and margarine (SGM).
\end{abstract}

Keywords: Training, Knowledge, PMT Modisco

\begin{abstract}
Abstrak: Modisco (Modified Dietetic Skim and Cotton Sheet Oil) merupakan makanan tambahan yang mengandung kalori tinggi untuk meningkatkan berat badan anak. Prosedur pembuatan PMT modisco sangat mudah karena terdiri dari tiga bahan dasar yaitu susu skim, gula dan margarine. Penelitian ini bertujuan untuk mengetahui pengaruh pelatihan terhadap pengetahuan Ibu tentang PMT modisco, pelatihan dengan metode ceramah dan demonstrasi. Jenis penelitian ini adalah preeksperimental dengan menggunakan desain one group pretest and posttest. Data pengetahuan menggunakan kuesioner, sampel penelitian ini adalah seluruh Ibu yang mempunyai anak Bawah Garis Merah (BGM) di Kelurahan Tanjungrejo Kecamatan Sukun Kota Malang sebanyak 11 orang. Hasil data pengetahuan menggunakan paired samplet t-test diketahui bahwa nilai Sig. (2-tailed) sebesar 0,000 $<0,05$ artinya terdapat keefektivitasan pelatihan terhadap pengetahuan Ibu terkait PMT modisco. Prosedur pembuatan PMT modisco dirasa tidak terlalu susah, ada tiga bahan dasar modisco yang dalam pelatihan disingkat dengan susu, gula, dan margarine (SGM).
\end{abstract}

Kata kunci: Pelatihan, Pengetahuan, PMT Modisco 
Anak berusia di bawah lima tahun (balita) merupakan anak yang rentan terhadap masalah kesehatan dan masalah gizi. Kurang Energi Protein (KEP) merupakan salah satu masalah gizi utama yang banyak dijumpai pada balita di Indonesia. Upaya untuk mengantisipasi masalah tersebut adalah diperlukan kesiapan dan pemberdayaan tenaga kesehatan dalam mencegah dan menanggulangi Kurang Energi Protein (KEP) berat/gizi buruk secara terpadu (Depkes, 2011).

Hasil dari Riskesdas dari tahun 2007 ke tahun 2013 menunjukkan fakta yang memprihatinkan dikarenakan underweight meningkat dari 18,4\% menjadi 19,6\% (Kemenkes RI, 2015). Masalah kesehatan masyarakat dianggap serius apabila prevalensi gizi buruk dan gizi kurang antara 20,0-29,0\%, dan dianggap prevalensi sangat tinggi bila $\geq$ $30 \%$. Pada tahun 2013, prevalensi gizi buruk dan gizi kurang pada anak balita secara Nasional sebesar 19,6\%, yang berarti masalah gizi buruk dan gizi kurang di Indonesia masih merupakan masalah kesehatan masyarakat yang mendekati prevalensi tinggi (Riskesdas, 2013).

Kurang Energi Protein (KEP) adalah seseorang yang kurang gizi yang disebabkan oleh rendahnya konsumsi energi dan protein dalam makanan sehari-hari dan gangguan penyakit tertentu. Anak disebut Kurang Energi Protein (KEP) apabila berat badannya kurang dari $80 \%$ indeks berat badan menurut umur (BB/U) WHO-NCHS. Kurang Energi Protein (KEP) adalah defisiensi gizi (energi dan protein) yang paling berat dan meluas terutama pada anak balita. Pada umumnya penderita Kurang Energi Protein (KEP) berasal dari keluarga menengah bawah yang berpenghasilan rendah (Supariasa, dkk, 2013).

Masalah gizi merupakan suatu masalah pada kesehatan masyarakat, namun penangulanganya tidak dapat dilakukan dengan pendekatan medis dan pelayanan kesehatan saja. Karena penyebab timbulnya masalah gizi adalah multifaktor, oleh karena itu pendekatan penanggulangannya harus melibatkan berbagai sektor yang terkait (Supariasa, dkk, 2013).

Salah satu cara untuk mengatasi kekurangan gizi yang terjadi pada usia balita perlu diselenggarakan Pemberian Makanan Tambahan (PMT). PMT bagi anak usia 6-59 bulan dimaksudkan sebagai tambahan, bukan sebagai pengganti makanan utama sehari-hari (Kemenkes, 2011).

Berdasarkan data dari Dinas Kesehatan Kota Malang prevalensi balita gizi buruk pada bulan Juli tahun 2016 sebanyak 57 balita $(0,093 \%)$ dari 60.911 balita yang ditimbang di Posyandu. Sedangkan balita gizi kurang di Kota Malang sebanyak 334 dari 60.911 balita yang ditimbang. Balita gizi buruk terbanyak ada di wilayah kerja Puskesmas Janti dan Puskesmas Pandanwangi (Dinkes Kota Malang, 2016). Di wilayah kerja Puskesmas Janti balita gizi buruk ada 7 balita, balita $2 \mathrm{~T}$ adalah balita tidak naik berat badannya 2 kali berturut-turut sebanyak 74 balita dan yang berada pada Bawah Garis Merah (BGM) sebanyak 31 anak dari 5.044 balita yang ditimbang. Diwilayah Puskesmas janti yang tertinggi ada di Kelurahan Tanjungrejo (Puskesmas Janti, 2017).

Upaya yang dilakukan dalam penanganan gizi kurang dan gizi buruk meliputi upaya promotif, preventif, kuratif dan rehabilitatif (Direktorat Jenderal Bina Gizi dan KIA, 2014). Upaya yang dilakukan oleh Pemerintah Kota Malang pada tahun 2017 untuk mencegah terjadinya gizi buruk dan gizi kurang melalui Dinas Kesehatan Kota Malang yaitu dengan menyalurkan bantuan Pemberian Makanan Tambahan (PMT) berupa biskuit yang didapatkan dari suplai Kementerian Kesehatan (Pemerintah Kota Malang, 2017).

Metode penanganan masalah gizi buruk sebagai upaya meningkatkan kesejahteraan anak studi kasus di rumah 
pemulihan gizi Yogyakarta Kusuma (2014) Lembaga Pos Keadilan Peduli Umat telah melakukan penanganan terhadap masalah gizi buruk melalui makanan tambahan yaitu modisco (modifikasi makanan tambahan) untuk pemulihan gizi buruk berupa kombinasi gula, susu, dan minyak goreng selama empat bulan dapat menaikkan berat badan anak penderita malnutrisi dan dampaknya dapat menurunkan angka balita gizi buruk.

Sebuah penelitian oleh Azizah, dkk (2012) menghasilkan suatu analisis dengan menggunakan uji statistik McNemar diperoleh hasil $\rho(0,125)>\alpha$ (0.05) maka H1 diterima yang berarti ada perbedaan antara balita yang diberikan PMT modisco dengan balita Bawah Garis Merah (BGM) yang tidak diberi modisco terhadap perubahan berat badan. Sebuah Studi pendahuluan penelitian yang dilakukan oleh Lubis Zulhaida \& Mardiyah I.S, (2015) terdapat peningkatan pengetahuan sesudah diadakan pelatihan tentang pembuatan makanan tambahan untuk balita, dimana persentase kader yang sebelumnya memiliki pengetahuan kurang sebanyak $93,3 \%$ turun menjadi $26,7 \%$.

Salah satu upaya menurunkan angka kejadian gizi buruk dan gizi kurang yaitu dengan diadakannya pelatihan pembuatan PMT modisco di Kelurahan Tanjungrejo Kecamatan Sukun Kota Malang. Meningkatkan pengetahuan Ibu sehingga PMT modisco bisa dijadikan sebagai alternatif PMT yang pembuatannya bisa dilakukan sendiri di rumah sebagai langkah penurunan kasus Kurang Energi Protein (KEP) di wilayah kerja Puskesmas Janti Kota Malang.

\section{METODE}

Motede penelitian yang digunakan adalah penelitian preeksperimental dengan desain penelitian one grup pretest posttest. Variabel bebas dalam penelitian ini adalah pelatihan pembuatan PMT modisco dan variabel terikat berupa pengetahuan. Sampel yang digunakan adalah 11 orang Ibu yang mempunyai anak Bawah Garis Merah (BGM) di Kelurahan Tanjungrejo Kecamatan Sukun Kota Malang.

Penelitian diawali dengan pretest untuk mengukur pengetahuan Ibu, kemudian ibu sebagai subyek penelitian diberikan perlakuan pelatihan dengan metode ceramah dan demonstrasi. Kemudian di ukur hasil perlakuan dengan mengadakan posttest pengetahuan.

Instrumen penelitian yang digunakan untuk mengukur variabel pengetahuan tentang PMT modisco yaitu dengan menggunakan kuesioner. Kuesioner adalah sebuah form yang berisi pertanyaan-pertanyaan yang telah ditentukan yang dapat difungsikan untuk pengumpulan data atau informasi dari dan tentang orang-orang sebagai bagian dari sebuah survey (Swarjana, 2015). Pemberian skor tes adalah dengan memberikan angka 0 (nol) setiap jawaban angka salah dan 1 (satu) setiap jawaban benar. Apabila sudah didapatkan hasilnya kemudian dikategorikan tinggi (baik) bila jawaban sesuai harapan sebesar 76-100\%, sedang (cukup) bila jawaban sesuai harapan sebesar 56-75\% dan rendah (kurang) bila jawaban sesuai harapan sebesar < 56\% (Nursalam, 2008).

Analisis data dalam penelitian ini diawali dengan uji persyaratan analisis, yakni berupa uji normalitas dan uji homogenitas, jika didapati data berdistribusi normal dan mempunyai varian yang homogen, maka dilanjutkan dengan pengujian hipotesis menggunakan paired sample t-test, tetapi jika data yang terkumpul tidak berdistribusi normal dan variansinya tidak homogen, maka pengujian hipotesis dilakukan dengan uji statistik non parametrik wilcoxon sugned ranks test.

\section{HASIL PENELITIAN}

Hasil penelitian disajikan pada tabel berikut: 
[Type text]

Tabel 1 Distribusi Umur

\begin{tabular}{ccc}
\hline Umur & Frekuensi & Persen \\
\hline $20-24$ & 3 & 27,3 \\
$25-29$ & 4 & 36,4 \\
$30-34$ & 3 & 27,3 \\
$35-39$ & 1 & 9,1 \\
\hline Total & 11 & 100,0 \\
\hline
\end{tabular}

Tabel 1 menunjukan bahwa dari 11 orang yang berumur $20-24$ tahun sebanyak 3 orang $(27,3 \%)$, yang berumur 25-29 tahun sebanyak 4 orang
(36,4\%), yang berumur 30- 34 tahun sebanyak 3 orang $(27,3 \%)$ dan yang berumur 35 - 39 sebanyak 1 orang $(9,1 \%)$.

Tabel 2 Distribusi Pendidikan Terakhir

\begin{tabular}{ccc}
\hline Pendidikan & Frekuensi & Persen \\
\hline SD & 4 & 36,4 \\
SMP & 4 & 36,4 \\
SMA & 3 & 27,3 \\
\hline Total & 11 & 100,0 \\
\hline
\end{tabular}

Tabel 2 menunjukan dari 11 orang Ibu terdapat 4 orang yang berpendidikan SD $(36,4 \%), 4$ orang yang berpendidikan

SMP $(36,4 \%)$, dan terdapat 3 orang berpendidikan SMA (27,3\%).

Tabel 3 Distribusi Pekerjaan

\begin{tabular}{ccc}
\hline Pekerjaan & Frekuensi & Persen \\
\hline IRT & 10 & 90,9 \\
BURUH & 1 & 9,1 \\
\hline Total & 11 & 100,0 \\
\hline
\end{tabular}

Tabel 3 menunjukan dari 11 orang Ibu terdapat 10 orang yang bekerja sebagai Ibu Rumah Tangga (90,9 \%), dan

Tabel 4 Data Hasil Pretest Pengetahuan

\begin{tabular}{ccc}
\hline Nilai & Frekuensi & Persen \\
\hline, 0 & 1 & 9,1 \\
10,0 & 1 & 9,1 \\
20,0 & 3 & 27,3 \\
30,0 & 1 & 9,1 \\
40,0 & 2 & 18,2 \\
50,0 & 3 & 27,3 \\
\hline Total & 11 & 100,0 \\
\hline
\end{tabular}

Tabel 4 menunjukan hasil pretest menghasilkan nilai tertinggi yang dicapai peserta pelatihan adalah 50 sebanyak 3 (tiga) orang dan nilai terdapat 1 orang Ibu yang bekerja sebagai buruh $(9,1 \quad \%)$. 
[Type text]

Tabel 5 Data Hasil Posttest Pengetahuan

\begin{tabular}{ccc}
\hline Nilai & Frekuensi & Persen \\
\hline 60 & 1 & 9,1 \\
70 & 3 & 27,3 \\
80 & 2 & 18,2 \\
90 & 3 & 27,3 \\
100 & 2 & 18,2 \\
\hline Total & 11 & 100,0 \\
\hline
\end{tabular}

Tabel 5 menunjukan hasil posttest menghasilkan nilai tertinggi yang dicapai peserta pelatihan adalah 100 sebanyak 2 (dua) orang dan nilai terendah adalah 60 sebanyak 1 (satu) orang. Nilai rata-rata sebesar 81,82 .

\begin{tabular}{|c|c|c|c|c|c|}
\hline Tabel & 6 & Pengkategorian & Hasil & Posttest & Pengetahuan \\
\hline Kategori & & Nilai & Frekuensi & & Persen \\
\hline Tinggi (Baik) & & $76-100$ & 7 & & 63,6 \\
\hline Sedang (Cukup) & & $56-75$ & 4 & & 36,4 \\
\hline Rendah (Kurang) & & $<56$ & 0 & & 0 \\
\hline Total & & & 11 & & 100,0 \\
\hline
\end{tabular}

Sumber : Nursalam, 2008.

Tabel 6 diketahui sesaat setelah diadakan pelatihan diketahui tujuh $(63,6$

$\%)$ Ibu memiliki pengetahuan yang tinggi (baik), empat (36,4 \%) Ibu memiliki pengetahuan yang sedang (cukup) mengenai PMT modisco.

Analisis

Tabel 7 Uji Normalitas

\begin{tabular}{cccc}
\hline & \multicolumn{3}{c}{ Shapiro-Wilk } \\
\cline { 2 - 4 } Pre_test & Statistik & df & Sig. \\
\cline { 2 - 4 } Post_Test &, 912 & 11 &, 257 \\
&, 927 & 11 &, 379 \\
\hline
\end{tabular}

Output uji normalitas variabel pengetahuan Ibu terkait PMT modisco menggunakan Shapiro-Wilk menunjukan 0,257 dan 0,379 . Apabila dibandingkan dengan nilai $\alpha=0,05$, diketahui nilai signifikansi lebih dari 0,05 ( $p>0,05$ ). Dengan demikian Ho diterima yang artinya data berdistribusi normal.

Tabel 8 Uji Homogenitas

\begin{tabular}{cccc}
\hline Levene Statistic & df1 & df2 & Sig. \\
\hline 1,219 & 1 & 20 &, 283 \\
\hline
\end{tabular}

Output uji homogenitas menunjukan 0,287 apabila dibandingkan dengan nilai $\alpha=0,05$, diketahui nilai

\section{Hasil Uji Hipotesis}

Hipotesis alternatif (Ha) yang diajukan dalam penelitian ini berbunyi signifikansi lebih dari $0,05(\mathrm{p}>0,05)$ maka data homogen.

"terdapat keefektivitasan pelatihan terhadap pengetahuan Ibu terkait PMT modisco di Kelurahan Tanjungrejo 
Kecamatan Sukun Kota Malang”, untuk kepentingan pengujian, hipotesis alternatif dalam penelitian ini diubah menjadi hipotesis nol (Ho) sehingga berbunyi "tidak ada keefektifitasan pelatihan terhadap pengetahuan Ibu terkait PMT modisco di Kelurahan Tanjungrejo Kecamatan Sukun Kota Malang". Hipotesis tersebut adalah hipotesis nol (Ho). Membuktikan hipotesis tersebut digunakan analisis statistik dengan Uji-t dengan taraf signifikansi $\alpha=0,05$. Hasil uji-t dikatakan diterima apabila harga $t_{\text {hitung }}>$ $t_{\text {tabel }}$ atau dengan nilai signifikansi < 0,05 . Perhitungan uji-t ini dilakukan dengan menggunakan IBM SPSS Statistics Version 20. Lebih jelasnya dapat dilihat pada tabel berikut:

Tabel 9 Paired Samples Test

\begin{tabular}{cccccc}
\hline Data & $\mathbf{T}_{\text {hitung }}$ & $\mathbf{T}_{\text {tabel }}$ & db & Sig. (2-taild) & Ket. \\
\hline Post-Test & $-15,392$ & $-44,571$ & 10 & 0,000 & $\mathrm{t}_{\mathrm{h}}>\mathrm{t}_{\mathrm{t}}=$ signifikan \\
\hline
\end{tabular}

Hasil perhitungan diperoleh $t_{\text {hitung }}$ sebesar $-15,392$, nilai negatif menunjukkan bahwa rerata posttest lebih tinggi dibandingkan dengan rerata pretest, jadi subjek mengalami peningkatan. Setelah dibandingkan dengan $t_{\text {tabel }}$ pada taraf signifikasi $\alpha=$ 0,05 dan $\mathrm{db}=10$, diperoleh nilai sebesar $-44,571$, ternyata $t_{\text {hitung }}$ lebih besar dari $\mathrm{t}_{\text {tabel. }}$.

Hasil uji paired samples test diatas juga diketahui bahwa nilai Sig. (2tailed) sebesar 0,000 $<0,05$, maka kedua indikator ini menunjukkan bahwa terdapat perbedaan yang signifikan antara prepost dan posttest pengetahuan, sehingga Ho yang berbunyi "tidak ada keefektivitasan pelatihan terhadap pengetahuan Ibu terkait PMT modisco di Kelurahan Tanjungrejo Kecamatan Sukun Kota Malang" ditolak. Maka Ha yang berbunyi "terdapat keefektivitasan pelatihan terhadap pengetahuan Ibu terkait PMT modisco di Kelurahan Tanjungrejo Kecamatan Sukun Kota Malang" diterima.

\section{PEMBAHASAN}

Berdasarkan hasil penelitian terhadap 11 Ibu di Kelurahan Tanjungrejo Kecamatan Sukun Kota Malang, disimpulkan bahwa terdapat keefektivitasan pelatihan terhadap pengetahuan. Hal ini mengindikasikan bahwa pelatihan adalah salah satu cara untuk meningkatkan pengetahuan. Pelatihan merupakan serangkaian kegiatan yang bertujuan untuk meningkatkan pengetahuan, keterampilan, dan sikap seseorang guna melaksanakan tugasnya.

Peningkatan pengetahuan yang diperoleh Ibu karena materi yang disampaikan dengan metode ceramah disertai dengan tanya jawab mengenai PMT modisco serta demonstrasi pembuatan PMT modisco mudah dimengerti oleh Ibu. Prosedur pembuatan PMT modisco dirasa tidak terlalu susah, ada tiga bahan dasar modisco yang dalam pelatihan disingkat dengan susu, gula, dan margarine (SGM).

Menurut Palutturi Sukri (2007) pelatihan memiliki arti yang luas bahwa sebagai salah satu usaha untuk mengembangkan sumber daya manusia terutama di dalam hal pengetahuan, kemampuan dan keterampilan. Suatu pelatihan yang didesain sesuai dengan kebutuhan pelatihan serta pengajaran yang dilakukan oleh instruktur yang kompeten akan sangat menentukan keberhasilan pelatihan. Pelatihan tidak hanya mengembangkan pengetahuan seseorang tetapi juga mempersiapkan mereka untuk terampil dalam melaksanakan tugasnya (Farooq, 2011).

Metode pelatihan dengan demonstrasi dan praktik memberikan keefektivitasan yang bermakna terhadap peningkatan pengetahuan. Pelatihan dengan metode ini memberikan kesan yang mendalam pada peserta. Peserta 
juga dilibatkan dalam kegiatan yaitu 7raktik. Hal ini sejalan dengan penelitian yang dilakukan oleh (Rapiasih, dkk, 2010) menyimpulkan bahwa ada peningkatan pengetahuan sesudah diadakan pelatihan dengan presentase sebelum $14,12 \%$ dan sesudah $71,00 \%$ peningkaatan sebesar $56,88 \%$.

Menurut Comer et al (2011) pelatihan meningkatkan pengetahuan dokter tentang risiko keselamatan terkait CVC, dan sebagian besar pengetahuan menurun hanya sekitar $12 \%$ dari waktu ke waktu. Ameeq et al (2013) membuktikan bahwa pelatihan berhubungan positif dan signifikan terhadap pengetahuan dan kinerja seseorang. Sejalan dengan penelitian (Sarbini D, Rahmawaty S 2008) sebelum diadakan pelatihan, nilai pengetahuan mengalami peningkatan yaitu rata-rata pretest $68,11 \%$ menjadi $97,74 \%$ atau memilik pengetahuan yang baik. Penelitian (Lubis Zulhaida \& Mardiyah I.S, 2015) terdapat peningkatan pengetahuan sesudah diadakan pelatihan kader tentang pembuatan makanan tambahan untuk balita, dimana persentase kader yang sebelumnya memiliki pengetahuan kurang sebanyak 93,3\% turun menjadi $26,7 \%$. Komponen yang dapat berpengaruh terhadap keberhasilan pelatihan antara lain yaitu kurikulum, pengajar/pelatih, penyelenggara, sarana yang digunakan, metode serta karakteristik peserta pelatihan seperti umur, pekerjaan, pendidikan, dan pengalaman.

Indikator keberhasilan pelatihan yaitu dengan adanya evaluasi kegiatan pelatihan yang dilakukan dengan membandingkan tingkat pengetahuan dan pemahaman peserta pelatihan sebelum dan sesudah pelatihan (Widyasanti, dkk 2016). Peserta pelatihan juga menyampaikan beberapa pesan, saran dan kesan sehingga data tersebut bisa menjadi bahan evaluasi pelaksanaan kegiatan pelatihan.
Pelatihan pembuatan PMT modisco memberikan hasil yang baik dalam meningkatkan pengetahuan Ibu. Pelatihan dilaksanakan dalam rangka memberikan pengetahuan, agar Ibu mampu membuat PMT modisco sendiri dirumah untuk menurunkan angka kejadian gizi kurang untuk mencegah gizi buruk.

Cara membuat segelas PMT modisco III, yang biasa diberikan untuk balita dengan status gizi kurang, penggunaan susunya $1 \frac{1 / 4}{\mathrm{sdm}}$, margarin $1 / 2$ sdm dan gula $1 \frac{1}{1 / 4}$ sdt dengan tambahan $100 \mathrm{ml}$ air dan menjadi 110 ml larutan modisco per gelas setelah dicampurkan.

Susu full cream sachet yang dijual di toko/warung dengan harga $\pm \mathrm{Rp}$. $14.000,-(200 \mathrm{gr})$ bisa untuk membuat \pm 16 kali PMT modisco. Margarin dengan harga \pm Rp. 7000,- perbungkus (250 gr), bisa 50 kali penggunaannya karena yang dibutuhkan dalam satu kali pembutan PMT modisco hanya $1 / 2 \mathrm{sdm}$ margarin (5 gr) saja. Begitu juga penggunaan gula \pm Rp. 3000,- (250 gr), bisa 30 kali penggunaannya. Jadi untuk membuat segelas PMT Modisco biaya yang dikeluarkan berkisar \pm Rp. 1500,-. Biaya \pm Rp. 1500,- bisa membuat minuman berkalori tinggi dan bermanfaat bagi anak dari pada menggunakan uang tersebut untuk jajanan kurang bergizi dan kurang sehat yang beredar dipasaran. Selain itu modisco bisa dibuat makanan lain seperti puding modisco, bolu modisco, kolak modisco, dan beraneka ragam makanan lain.

\section{KESIMPULAN}

Berdasarkan hasil-hasil analisis dan pembahasan yang telah diuraikan pada bagian sebelumnya, maka dapat ditarik kesimpulan yaitu :

Terdapat keefektivitasan pelatihan terhadap pengetahuan Ibu terkait PMT modisco di Kelurahan Tanjungrejo Kecamatan Sukun Kota Malang. Peningkatan pengetahuan Ibu mengenai PMT Modisco meningkat setelah diadakan pelatihan, diketahui bahwa nilai Sig. (2-tailed) sebesar 0,000 $<0,05$ 
artinya terdapat keefektivitasan pelatihan terhadap pengetahuan Ibu terkait PMT modisco.

\section{SARAN}

Hasil penelitian yang telah dilakukan, maka sebagai usaha untuk mengurangi kasus gizi kurang dan buruk disarankan hal berikut:

a. Diharapkan ibu mempraktekannya sendiri di rumah dan memberikan modisco kepada balita, supaya menurunkan kejadian gizi kurang serta dapat mencegah kasus gizi buruk di kelurahan Tanjungrejo Kecamatan Sukun Kota Malang.

b. Kepada tenaga kesehatan khususnya tenaga kesehatan di instalasi gizi diharapkan agar dapat melaksanakan penyuluhan dan pelatihan, khususnya tentang penanggulangan gizi kurang dan buruk.

c. Bagi peneliti lain, diharapkan menjadi bahan pertimbangan apabila melakukan penelitian serupa atau lanjutan dengan memberikan modisco secara langsung kepada balita kemudian melihat perubahan berat badan balita.

\section{DAFTAR RUJUKAN}

Ameeq, Ul Ameeq and Hanif, F. 2013. Impact of Training on Employee's Development and Performance in Hotel Industry of Lahore, Pakistan.

Journal of Business Studies Quarterly Vol. (4), No. (5).

Azizah N, Suyati, Zakiyah. 2012. Perbedaan Antara Balita BGM yang Diberikan PMT Modisco dengan Balita BGM yang Tidak Diberikan PMT Modisco terhadap Perubahan Berat Badan. Jombang: Universitas Pesantren Tinggi Darul Ulum Jombang.

Departemen Kesehatan RI. 2011. Pedoman dan Tata Laksana Kurang Energi Protein pada Anak Puskesmas dan Rumah Tangga. Jakarta: Departemen Kesehatan RI.
Dinas Kesehatan Kota Malang. 2016. Data Balita Gizi Buruk Kota Malang 2016. Malang: Dinkes Kota Malang.

Comer, et al. 2011. Web-Based Training Improves Knowledge about Central Line Bloodstream Infections. Infect Control Hosp Epidemi Vol. (12), No. (32).

Farooq M. 2011. Impact of Training and Feedback on Employee Performance. Journal of Psychology and Business Vol (5) No (1).

Kementerian Kesehatan RI. 2015. Rencana Stategis Kementerian Kesehatan Tahun 2015-2019. Jakarta: Kementerian Kesehatan RI.

Kementerian Kesehatan. 2011. Panduan Penyelenggaraan Pemberian Makanan Tambahan Pemulihan Bagi Balita Gizi Kurang. Jakarta: Ditjen Bina Gizi dan Kesehatan Ibu dan Anak Kementerian Kesehatan RI.

Kusuma Wardani, T. 2014. Metode Penanganan Masalah Gizi Buruk Sebagai Upaya Untuk Meningkatkan Kesejahteraan Anak. Yogyakarta: Universitas Islam Negeri Sunan Kalijaga.

Nursalam. 2008. Konsep dan Penerapan Metodologi Penelitian Ilmu Keperawatan. Jakarta: Penerbit Salemba Medika.

Puskesmas Janti. 2016. Data Balita Gizi Buruk 2016. Malang: Puskesmas Janti.

Rapiasih, dkk. 2010. Pelatihan hygiene sanitasi dan poster berpengaruh terhadap pengetahuan, perilaku penjamah makanan, dan kelaikan hygiene sanitasi di instalasi gizi RSUP Sanglah Denpasar. Jurnal Gizi Klinik Indonesia Vol. (7). No. (2).

Riskesdas. 2013. Riset Kesehatan Dasar. Jakarta: Badan Penelitian dan Pengembangan Kesehatan Kementerian Kesehatan RI. 
Sarbini, D, Rahmawaty, S, 2008. Pelatihan membuat MP-ASI lokal dengan bahan dasar BMC (bahan makanan campuran) untuk balita pada kader posyandu di wilayah. Jurnal Warta Vol .(11), No.

Sukri Palutturi, Nurhayani, Nurhamsa Mandak. 2007. Determinan Kinerja Bidan Di Puskesmas Tahun 2006. Jurnal Manajemen Pelayanan Kesehatan, Vol. (10), No. (4).

Supariasa, I.D.N., Bakri, B., dan Fajar I, I. 2013. Penilaian Status Gizi. Jakarta: EGC.

Swarjana, I Ketut 2015. Metodologi Penelitian Kesehatan: Tuntutan
Praktis Pembuatan Proposal Penelitian untuk Keperawatan, Kebidanan, dan Profesi Bidang Kesehatan Lainnya. Yogyakarta: Andi.

Widyasanti, A. Putri, S.H.dan Dwiratna S.N.P. Upaya Pemberdayaan Masyarakat Melalui Pelatihan Pembuatan Produk Sabun Berbasis Komoditas Lokal Di Kecamatan Sukamantri Ciamis. Jurnal Vol (5) No (1).

Zulhaida Lubis, Isyatun Mardiyah Syahri. 2015. Pengetahuan dan Tindakan Kader Posyandu dalam Pemantauan Pertumbuhan Anak Balita. Jurnal Kemas Vol (1) No (11). 